\title{
ANALISIS INFLASI MENGGUNAKAN DATA GOOGLE TRENDS DENGAN MODEL ARIMAX DI DKI JAKARTA*
}

\author{
Newton $^{1}$, Anang Kurnia ${ }^{2 \ddagger}$, and I Made Sumertajaya ${ }^{3}$ \\ 1Department of Statistics, IPB University, Indonesia, newton0689@gmail.com \\ 2Department of Statistics, IPB University, Indonesia, anangk@apps.ipb.ac.id \\ 32Department of Statistics, IPB University, Indonesia, imsjaya.stk@gmail.com \\ Fcorresponding author
}

Indonesian Journal of Statistics and Its Applications (elSSN:2599-0802) Vol 4 No 3 (2020), 545 - 556

Copyright (c) 2020 Newton, Anang Kurnia, and I Made Sumertajaya. This is an open-access article distributed under the Creative Commons Attribution License, which permits unrestricted use, distribution, and reproduction in any medium, provided the original work is properly cited.

\begin{abstract}
Inflation is one of the important economic indicators to show economic symptoms of region's price level. DKI Jakarta is the capital city of Indonesia which is chosen as the center of the economic barometer because it can provide the largest contribution and influence to the Indonesian economy. ARIMAX model is used to estimate by adding independent variables in Google Trends data. Google Trends data is explored based on seven expenditure groups published by CPI and Google Trends data is used from January 2013 to March 2019. The purpose of this study was to compare the best forecasts through the ARIMA and ARIMAX model approaches by using BPS data and the results of the exploration of Google Trends data, interest rate data, exchange rate data to see the effect of inflation in DKI Jakarta. Specifically, this research explores whether Google Trends data can provide good information in forecasting inflation in DKI Jakarta. The results of data analysis indicate that the forecasting results are close to the original BPS data with the best forecasting model, namely $\operatorname{ARIMAX}(2,0,3)$ all $X$ variables. Forecasting using Google trends data is good enough to be used in forecasting inflation, especially in DKI Jakarta.
\end{abstract}

Keywords: ARIMAX, forecasting, google trends, inflation.

"Received Aug 2020; Accepted Nov 2020; Published online on Nov 2020 


\section{Pendahuluan}

Inflasi merupakan salah satu faktor ekonomi yang penting dalam pertumbuhan ekonomi suatu negara. Badan Pusat Statistik (BPS) mendefinisikan inflasi sebagai peningkatan harga barang dan jasa terhadap kebutuhan masyarakat secara rata-rata. Kebutuhan akan ketersedian barang dan jasa perlu dikendalikan agar tidak terjadi laju inflasi. Menurut Pratidina (2012) pentingnya pengendalian inflasi dikarenakan inflasi yang tinggi menimbulkan dampak negatif terhadap kondisi sosial ekonomi masyarakat.

Inflasi merupakan indikator ekonomi penting dalam menunjukkan gejala ekonomi tingkat harga suatu wilayah. Indeks harga konsumen (IHK) adalah salah satu indikator ekonomi makro dan digunakan dalam mengukur inflasi suatu wilayah ([BPS], 2017). Berdasarkan hasil survey biaya hidup (SBH), IHK digunakan oleh BPS untuk memonitor perkembangan harga barang dan jasa di setiap kabupaten atau kota pada tujuh kelompok pengeluaran. Tujuh kelompok pengeluaran tersebut adalah bahan makanan, makanan jadi, transportasi, pendidikan, kesehatan, sandang, dan perumahan. Selain itu ada indikator tambahan lain yang mempengaruhi inflasi yaitu nilai tukar dan suku bunga.

Pengendalian inflasi di Indonesia dikendalikan oleh Bank Indonesia karena pada dasarnya pembentukan inflasi nasional merupakan angka agregat dari inflasi regional. Sebagai bukti, inflasi nasional dihitung berdasarkan rataan dari beberapa kota yang disurvei oleh BPS. Kota DKI Jakarta merupakan ibukota Indonesia dipilih sebagai sentra barometer perekonomian, karena dapat memberikan kontribusi dan pengaruh paling besar pada perekonomian Indonesia. Pada Desember 2019, BPS mencatat DKI Jakarta mengalami inflasi 0.30 persen yang disebabkan naiknya harga bahan makanan sebesar 0.94 persen. Selama Januari-Desember tahun 2019 inflasi di DKI Jakarta mencapai 3,23 persen, lebih rendah dari inflasi pada periode yang sama tahun sebelumnya yaitu sebesar 3,27 persen ([BPS], 2019).

Demi terwujudnya kestabilan inflasi yang akan memberikan dampak postitif bagi perekonomian maka salah satu upaya yang dapat dilakukan adalah peramalan (forecasting). Secara umum, perhitungan peramalan dapat menggunakan data deret waktu. Menurut Wei (2006) data deret waktu adalah pengamatan berdasarkan urutan waktu dan antara pengamatan yang berdekatan memiliki korelasi, yaitu setiap pengamatan dari suatu peubah, berkorelasi dengan peubah itu sendiri pada waktu sebelumnya.

Salah satu model deret waktu yang banyak digunakan adalah ARIMA (Autoregressive Integrated Moving Average). Model ARIMA adalah model yang sederhana karena hanya melibatkan perilaku dari peubah itu sendiri atau peubah tunggal. Salah satu modifikasi dari ARIMA adalah Autoregressive Integrated Moving average with exogenous (ARIMAX). Pada model ARIMAX, peubah-peubah lain yang memiliki pengaruh signifikan terhadap data ditambahkan ke dalam pemodelan deret waktu ARIMAX untuk meningkatkan nilai akurasi. Telah banyak literatur yang mengkaji mengenai pemodelan inflasi dengan menggunakan teknik analisis deret waktu. Stephani et al. (2015) melakukan penelitian pemodelan inflasi nasional berdasarkan faktor ekonomi makro menggunakan pendekatan time series klasik dan ANFIS. Eksiandayani, (2016) melakukan penelitian tentang peramalan inflasi umum dan inflasi menurut kelompok pengeluaran dengan metode hibrida ARIMAX-NN. 
Penelitian inflasi menggunakan model ARIMAX dengan menambahkan peubah seperti nilai tukar rupiah terhapad dollar Amerika, suku bunga, dan peubah bebas lain sudah banyak dilakukan. Perlu dilakukan penambahan peubah eksogen luar yang diharapkan akan mampu mengungkap pengaruh lainnya. Alternatif yang dapat digunakan adalah menggunakan data google trends. Google trends adalah salah satu platform yang disediakan oleh Google Inc yang mampu mengungkap data dan grafik.

Google trends mampu mengungkap hasil penelusuran berdasarkan kategori, waktu, lokasi kueri, dan jenis penelusuran. Keakuratan data Google trends pertamakali diteliti oleh Choi \& Varian (2012) untuk meramal pembelian mobil, penjualan ritel, dan pembelian perumahan di Amerika dengan menggunakan model autoregresif. Vicente et al. (2015) menggunakan data Google trends dalam meramalkan pengangguran di negara Spayol dengan model ARIMAX. Pati \& Padhi (2017) menggunakan model ARIMAX untuk memperkirakan kedatangan dan tujuan wisata menggunakan data Google trends di kota Kerala.

Berdasarkan uraian diatas, penelitian ini bertujuan adalah membandingkan ramalan terbaik melalui pendekatan model ARIMA dan ARIMAX dengan mengunakkan data BPS dan hasil eksplorasi data Google Trends, data suku bunga, data nilai tukar untuk melihat pengaruh inflasi di DKI Jakarta. Secara spesifik, pada penelitian ini dieksplorasi apakah data Google Trends mampu memberikan informasi yang baik dalam peramalan inflasi di DKI Jakarta.

\section{Metodologi}

\subsection{Data}

Data yang akan digunakan dalam penelitian ini adalah Inflasi Provinsi DKI Jakarta mulai dari Januari 2013 sampai dengan Maret 2019. Data inflasi didapatkan dari hasil publikasi BPS, data nilai tukar Rupiah terhadap Dollar dan suku bunga didapatkan publikasi Bank Indonesia (BI), data kelompok pengeluaran berdasarkan Google trends. Peubah bebas dan peubah respon bebas yang digunakan terdapat pada Tabel 1.

\section{$2.2 \quad$ Metode}

Adapun langkah-langkah yang dilakukan dalam penelitian ini adalah sebagai berikut:

1. Persiapan data

Data dibagi menjadi dua bagian yaitu data training (Januari 2013-September 2018) dan data testing (Oktober 2018-Maret 2019).

2. Eksplorasi data untuk mengetahui stasioneritas data dan mendapatkan kandidat model.

Eksplorasi pola menggunakan uji Augmented Dicky-Fuller (ADF) untuk mengecek stasioneritas data. Selanjutnya dengan menggunakan plot Autocorrelation Function (ACF) dan plot Parsial Autocorrelation Function (PACF) untuk mendapatkan kandidat model yang terbaik. 
Tabel 1: Peubah respon dan peubah penjelas

\begin{tabular}{cll}
\hline Jenis Peubah & Peubah & \multicolumn{1}{c}{ Nama peubah } \\
\hline Peubah Respon & Y & $\begin{array}{l}\text { Inflasi DKI Jakarta (\%) } \\
\text { Kelompok bahan makanan dan Kelompok } \\
\text { makanan jadi (popularitas relatif) }\end{array}$ \\
& RMH & $\begin{array}{l}\text { Kelompok perumahan } \\
\text { Kelompok transportasi, jasa keuangan, dan } \\
\text { komunikasi (popularitas relatif) } \\
\text { Kelompok pendidikan, rekreasi, dan } \\
\text { Tlahraga (popularitas relatif) }\end{array}$ \\
& SDG & $\begin{array}{l}\text { Kelompok sandang (popularitas relatif) } \\
\text { Kelompok kesehatan (popularitas relatif) }\end{array}$ \\
& KSN & $\begin{array}{l}\text { Inflasi umum Google trends (popularitas } \\
\text { relatif) }\end{array}$ \\
& NT & $\begin{array}{l}\text { Nilai tukar Rupiah terhadap Dollar US } \\
\text { (Rp/USD) }\end{array}$ \\
& SB & $\begin{array}{l}\text { Suku bunga Bank Indonesia (\%) } \\
\text { Dummy (Pemilu, Ramadhan/Hari raya Idul } \\
\text { Fitri, tahun ajaran baru) }\end{array}$ \\
&
\end{tabular}

3. Pemodelan ARIMA

a. Model ARIMA terbaik yang diperoleh dari uji ADF serta plot ACF dan PACF. Pemilihan model terbaik berdasarkan AIC terkecil.

b. Melakukan diagnostik, peramalan dan evaluasi ramalan.

4. Pemodelan ARIMAX

a. Menggunakan model ARIMA berdasarkan model terbaik langkah 3.

b. Pemodelan ARIMAX dilakukan dengan penambahan peubah suku bunga, nilai tukar, tujuh kelompok pengeluaran Google trends (Inflasi GT, GT makan, GT perumahan, GT kesehatan, GT transportasi, GT pendidikan, GT sandang) dan dummy. Untuk dummy terdiri dari gabungan pemilu, Ramadhan/Hari raya Idul Fitri, tahun ajaran baru dengan nilai 1.

c. Membentuk kandidat-kandidat model:

i. ARIMAX dengan masing-masing peubah suku bunga, nilai tukar, dan tujuh kelompok pengeluaran Google Ttrends.

ii. ARIMAX dengan semua peubah variabel yang independent (suku bunga, nilai tukar, dan tujuh kelompok pengeluaran Google trends.

d. Membentuk kandidat-kandidat model dengan distribusi lag.

cross correlation function (CCF) digunakan untuk melihat korelasi silang antara dua bebas $X$, antara peubah Inflasi BPS dengan semua peubah penjelas untuk menggetahui jarak waktu (lag)

i. ARIMAX dengan distribusi $\mathrm{Lag}$

ii. ARIMAX dengan distribusi Lag dan dummy

e. Melakukan evaluasi pada langkah (c) dan (d) berdasarkan pengaruh nilai AIC terkecil. Evaluasi ramalan akan dibandingkan dengan data BPS.

5. Memilih estimasi model terbaik dari model ARIMA dan ARIMAX dengan kandidatkandidat sebelumnya. 
6. Evaluasi model dengan menghitung mean absolute error (MAPE) dan mean square error (MSE)

7. Pemilihan model terbaik berdasarkan hasil ramalan model.

\section{Hasil dan Pembahasan}

\subsection{Eksplorasi Data}

Eksplorasi data merupakan tahap awal yang dilakukan untuk mengidentifikasi model. Langkah awal akan dilihat perbandingan inflasi pada data Google trends. Perbandingan inflasi dan inflasi Google trends DKI Jakarta dari bulan Januari 2013 sampai dengan Januari akan ditunjukkan oleh Gambar 1.

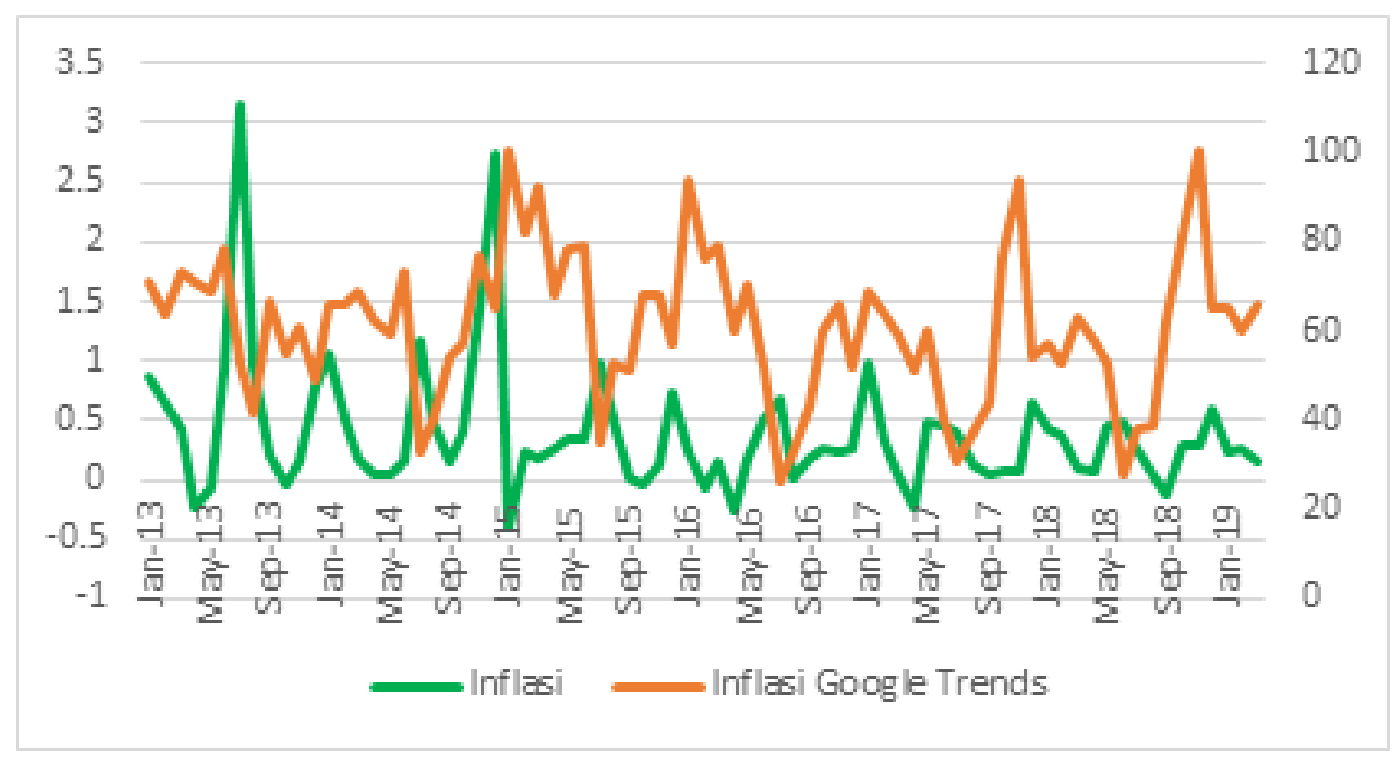

Gambar 1: Plot perbandingan inflasi dan inflasi Google trends DKI Jakarta dari Januari 2013 sampai Januari 2019.

Gambar 1 menunjukkan grafik inflasi Google trends menunjukkan pola stabil. Pada titik tertentu inflasi Google trends menunjukkan titik yang hampir sama dengan inflasi aktual DKI Jakarta. Namun di beberapa titik kejadian inflasi aktual menunjukkan inflasi bergerak naik yang diikuti dengan inflasi Google trends. Untuk tujuh kelompok pengeluaran data Google trends, yang memberi pengaruh penelusuran terbesar yaitu transportasi dan pendidikan yang ditunjukkan oleh Gambar 2. 


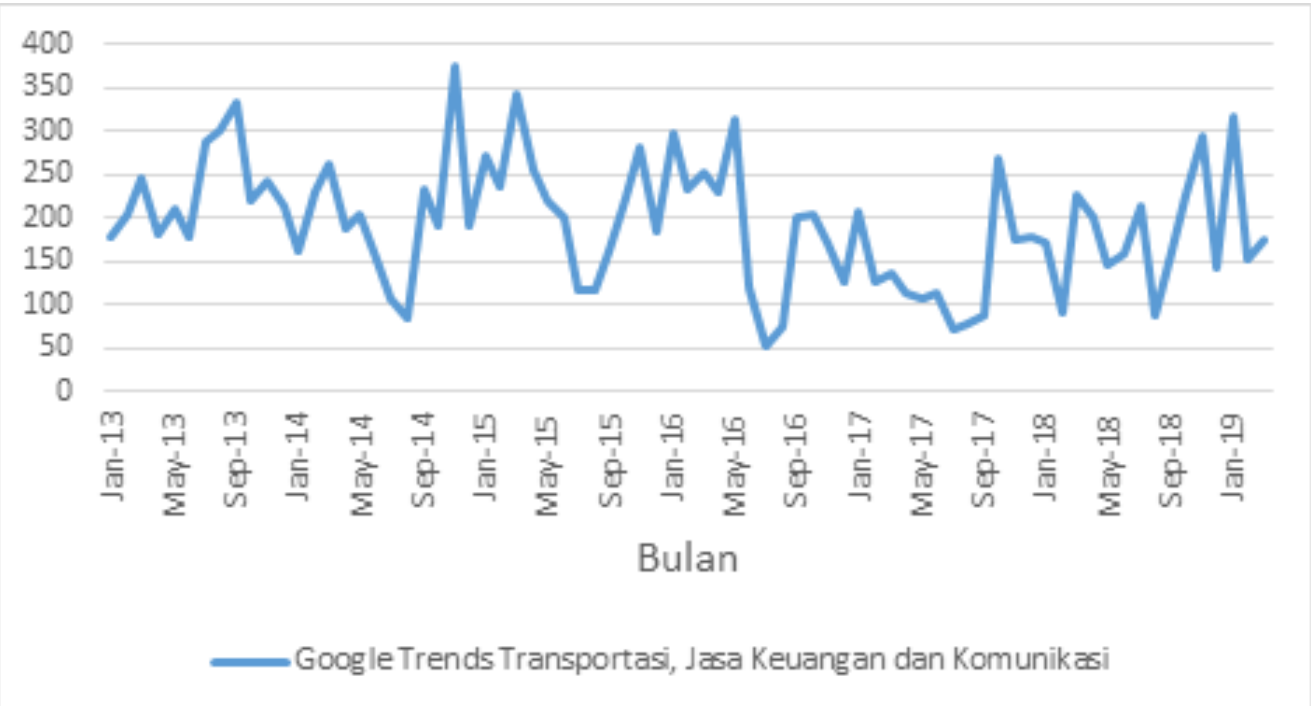

Gambar 2: Google trends transportasi, jasa keuangan dan komunikasi dari bulan Januari 2013 sampai Maret 2019.

Gambar 2 menunjukkan bahwa penelusuran terhadap bidang Transportasi, Jasa Keuangan dan Komunikasi relative besar. Google trends mencatat penelusuran tertinggi terjadi pada bulan Januari 2016 dan 2019. Tingkat penelusuran paling sedikit terjadi pada bulan Februari 2018.

\subsection{Model Autoregressive Integrated Moving Average (ARIMA)}

Identifikasi orde pada model ARIMA dilakukan dengan melihat pola data yang sudah stasioner. Pemeriksaan stasioneritas dapat dilakukan dengan plot ACF dan PACF. Hasil plot ACF dan PACF ditunjukkan oleh Gambar 3.

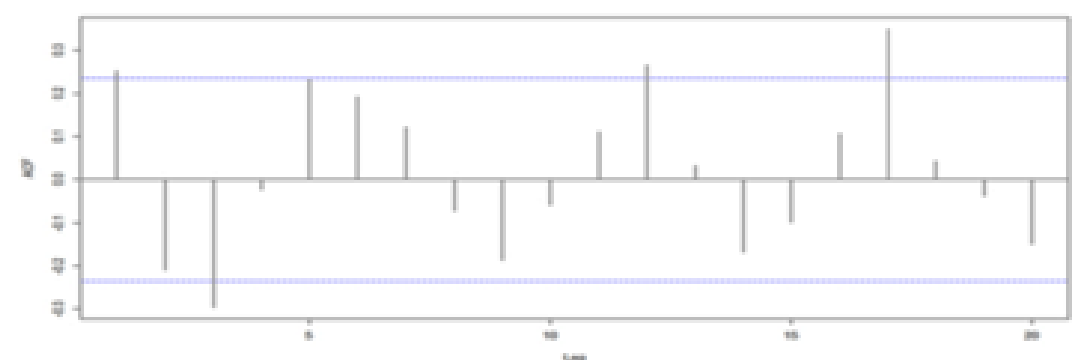

(a)

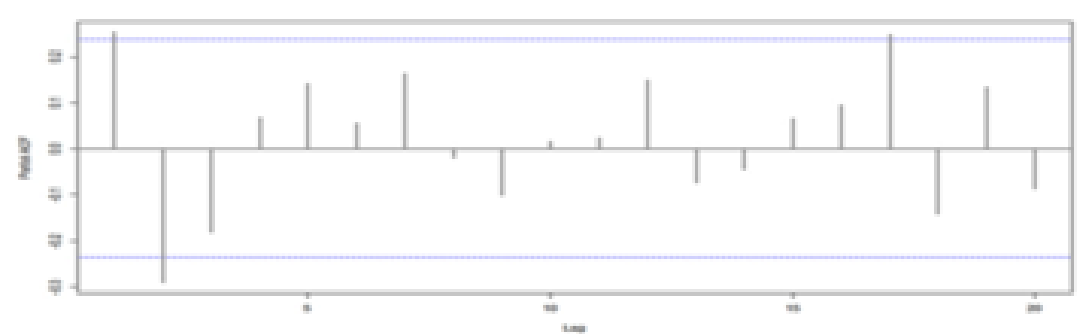

(b)

Gambar 3: Plot (a) ACF dan (b) PACF 
Pada Gambar 3(a) mengindikasikan bahwa plot ACF menunjukkan ordo 2 atau AR(2) dan Gambar 3(b) plot PACF menunjukkan ordo 3 atau MA(3). Didapatkan kandidat model ARIMA berdasarkan ACF dan PACF adalah ARIMA(2.0.0), $\operatorname{ARIMA}(0.0 .3)$ dan ARIMA(2,0,3).

Ukuran keakuratan ramalan yang digunakan untuk mengidentifikasi model adalah Akaike's Information Criterion (AIC). Berdasarkan tiga model diatas didapatkan nilai AIC terkecil yaitu model ARIMA $(2,0,3)$ dengan nilai AIC 108.92 sebagai model terbaik.

Pemeriksaan diagnostik ada model pada model $\operatorname{ARIMA}(2,0,3)$ dengan uji ShapiroWilk dengan nilai $p$-value lebih kecil dari 5 persen dan uji Ljung-Box tidak terdapat autokorelasi. Disimpulkan bahwa model $\operatorname{ARIMA}(2,0,3)$ telah memenuhi asumsi independent (saling bebas).

\subsection{Model Autoregssive Integrated Moving Average Exogenous (ARIMAX)}

Pembentukan model ARIMAX dilakukan berdasarkan model terbaik yang didapatkan sebelumnya yaitu dari model ARIMA $(2,0,3)$. Pada penelitian ini model ARIMAX dibagi berdasarkan peubah bebas dan berdasarkan lag. Penentuan lag dari peubah $X$ dilakukan dengan mancari nilai fungsi korelasi silang atau CCF (cross correlation function). Salah satu hasil lag yang signifikan akan ditunjukkan oleh Gambar 4.

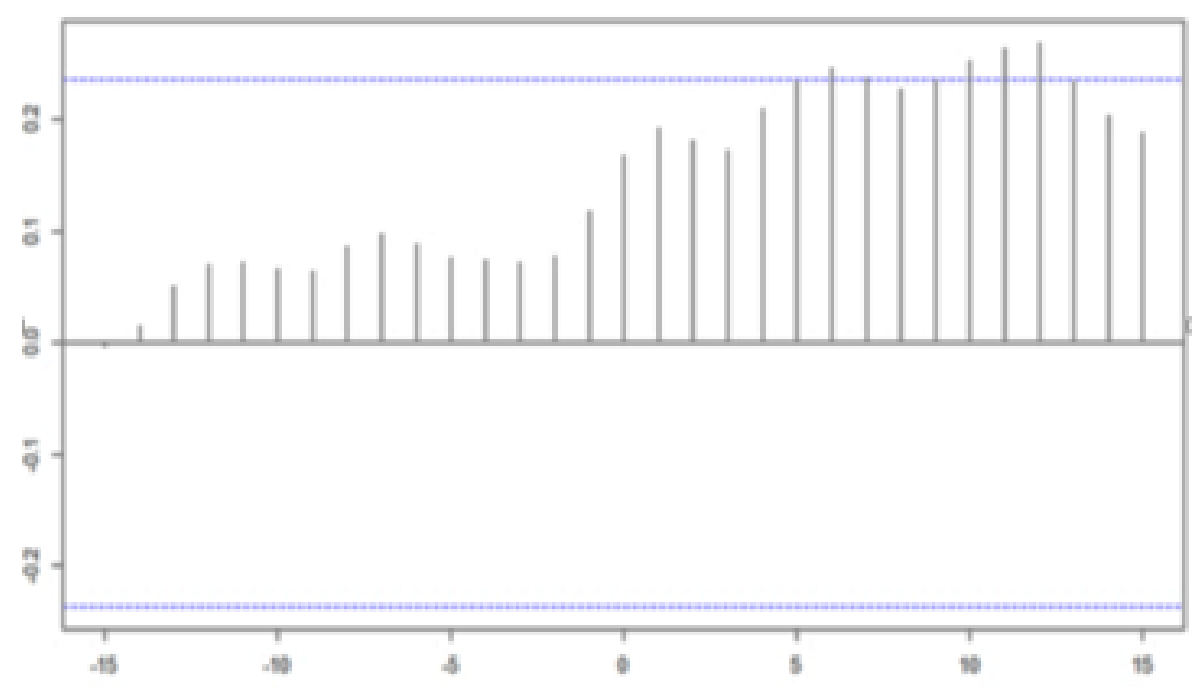

Gambar 4: Hasil lag signifikan untuk suku bunga

Gambar 4 menunjukkan bahwa suku bunga dengan lag signifikan pada lag 6 , hal ini terjadi setelah 6 bulan inflasi terjadi. Variabel GT transportasi lag yang signifikan pada lag 3. Untuk variabel GT sandang dengan lag yang signifikan pada lag 4. Untuk variabel yang tidak signifikan akan dipakai lag 0 . Untuk dummy adalah gabungan dari pemilu, Ramadhan/Hari raya Idul Fitri, tahun ajaran baru dengan nilai dummy $=1$. Berdasarkan fungsi CCF pada variabel $X$, beberapa variabel yang signifikan adalah suku bunga, GT transportasi dan GT sandang. 


\subsubsection{Model ARIMAX, Suku Bunga, Nilai Tukar dan Tujuh Kelompok Pengeluaran Google Trends}

Perhitungan model ARIMA $(2,0,3)$ dengan peubah-peubah bebas $(X)$ bertujuan untuk melihat pengaruh terhadap inflasi. Peubah bebas seperti suku bunga, nilai tukar, Inflasi GT, GT makanan, GT makanan, GT perumahan, GT kesehatan, GT transportasi, GT perumahan, GT pendidikan, GT sandang akan menjadi peubah dalam pembentukan model ARIMAX. Didapatkan hasil bahwa masing-masing peubah bebas terhadap model ARIMAX $(2,0,3)$ tidak cukup kuat mempengaruhi model. Hasil $p$-value menunjukkan semua model tidak ada yang signifikan pada taraf 5 persen.

\subsubsection{Model ARIMAX Semua Peubah Bebas}

Variable signifikan terhadap semua peubah bebas adalah pemodelan $\operatorname{ARIMAX}(2,0,3)$ hasil inflasi GT dan GT makan. Hal ini dipengaruhi oleh penelusuran yang sering dicari pada Google search. Kedua peubah tersebut menjadi yang paling banyak dicari karena berhubungan dengan dampak kenaikan inflasi. Meskipun GT Pendidikan tidak signifikan terhadap model tetapi mengindikasikan mempunyai pengaruh terhdap inflasi.

Tabel 2: Dugaan parameter model ARIMAX semua peubah bebas $X$

\begin{tabular}{lrrrr}
\hline \multicolumn{1}{c}{ Peubah } & $\begin{array}{c}\text { Dugaan } \\
\text { Parameter }\end{array}$ & Galat Baku & $t$-hitung & $p$-value \\
\hline Intersep & 0.9486 & 0.6567 & 1.4445 & 0.1486 \\
MA(1) & -0.5010 & 0.3712 & -1.3497 & 0.1771 \\
MA(2) & -0.0954 & 0.2968 & -0.3214 & 0.7479 \\
MA(3) & -0.4036 & 0.2129 & -1.8957 & 0.0581 \\
AR(1) & 0.4201 & 0.4018 & 1.0456 & 0.2958 \\
AR(2) & -0.1773 & 0.2775 & -0.6389 & 0.5229 \\
Suku bunga & 0.0751 & 0.0252 & 2.9802 & $\mathbf{0 . 0 0 2 9}$ \\
Nilai tukar & $-7.9926 \times 10^{-5}$ & $3.5911 \times 10^{-5}$ & -2.2256 & $\mathbf{0 . 0 2 6 0}$ \\
Inflasi GT & -0.0135 & 0.0066 & -2.0455 & $\mathbf{0 . 0 4 0 2}$ \\
GT Makanan & 0.0030 & 0.0016 & 1.8750 & $\mathbf{0 . 0 5 7 4}$ \\
GT Perumahan & 0.0015 & 0.0010 & 1.5000 & 0.1241 \\
GT Kesehatan & $3.8413 \times 10^{-5}$ & 0.0017 & 0.0226 & 0.9824 \\
GT Transportasi & 0.0007 & 0.0010 & 0.7000 & 0.4594 \\
GT Pendidikan & 0.0026 & 0.0016 & 1.6250 & $\mathbf{0 . 0 9 7 9}$ \\
GT Sandang & -0.0020 & 0.0025 & -0.8000 & 0.4222 \\
\hline
\end{tabular}

\subsubsection{Model ARIMAX dengan Distribusi Lag}

Hasil model ARIMAX $(2,0,3)$ sebelumnya, dengan variabel yang sudah signifikan menggunakan fungsi CCF akan digunakan untuk melihat pengaruh inflasi. Peubah yang signifikan yaitu suku bunga (lag 6), GT transportasi (lag 3), GT sandang (lag 4), dan GT makanan (lag 0). GT makan akan digunakan pada model bertujuan untuk melihat pengaruh pencarian makan pada Google walaupun tidak signifikan.Model 
ARIMAX(2,0,3) dengan memodelkan semua peubah menghasilkan dugaan parameter ditunjukkan pada Tabel 3.

Tabel 3: Dugaan Parameter Model ARIMAX Distribusi Lag

\begin{tabular}{lrlrr}
\hline \multicolumn{1}{c}{ Peubah } & $\begin{array}{l}\text { Dugaan } \\
\text { Parameter }\end{array}$ & $\begin{array}{l}\text { Galat } \\
\text { Baku }\end{array}$ & \multicolumn{1}{c}{-hitung } & \multicolumn{1}{c}{$p$-value } \\
\hline Intersep & 0.1279 & 0.3722 & 0.3436 & 0.7312 \\
MA(1) & -0.7951 & 0.1561 & -5.0935 & $3.515 \times 10^{-7}$ \\
MA(2) & 0.7238 & 0.1808 & 4.0033 & $6.231 \times 10^{-5}$ \\
MA(3) & 0.2614 & 0.1551 & 1.6854 & 0.0919 \\
AR(1) & 0.9711 & 0.0298 & 32.5873 & $2.2 \times 10^{-16}$ \\
AR(2) & -0.9878 & 0.0179 & -55.1844 & $2.2 \times 10^{-16}$ \\
\hline
\end{tabular}

\begin{tabular}{lrlrr}
\hline \multicolumn{1}{c}{ Peubah } & $\begin{array}{l}\text { Dugaan } \\
\text { Parameter }\end{array}$ & $\begin{array}{l}\text { Galat } \\
\text { Baku }\end{array}$ & \multicolumn{1}{c}{$t$-hitung } & \multicolumn{1}{c}{$p$-value } \\
\hline Suku Bunga(lag6) & 0.0592 & 0.0590 & 1.0034 & 0.3159 \\
GT TKU (lag 3) & -0.0010 & 0.0010 & -1.0000 & 0.3352 \\
GT Sandang (lag4) & 0.0004 & 0.0020 & 0.2000 & 0.8271 \\
GT Makanan (lag 0) & 0.0015 & 0.0017 & 0.8824 & 0.3833 \\
\hline
\end{tabular}

Tabel 3 menunjukkan bahwa hasil bahwa dugaan parameter model ARIMAX $(2,0,3)$ pada masing-masing peubah dengan distribusi lag tidak cukup kuat mempengaruhi model. Pengaruh dari lag yang berbeda-beda pada setiap peubah bebas menyebabkan tidak ada perubahan yang signifikan. Disimpulkan bahwa peubah bebas tidak mengindikasikan mempengaruhi inflasi.

\subsubsection{Model ARIMAX Lag dan Dummy}

Tahapan yang sama juga dilakukan pada peubah dummy. Model ARIMAX $(2,0,3)$ dengan variabel yang sudah signifikan menggunakan fungsi CCF dengan penambahan variabel dummy. Hasil dengan penambahan dummy di tunjukkan oleh Tabel 4.

Tabel 4 menunjukkan bahwa bahwa masing-masing peubah bebas terhadap model ARIMAX(2,0,3) dengan distribusi lag dan dummy tidak yang cukup kuat mempengaruhi model. Untuk dummy yang menunjukkan tidak signifikan mengindikasikan bahwa dummy mempengaruhi inflasi. Disimpulkan bahwa dummy untuk pemilu, Ramadhan/Hari raya Idul Fitri, tahun ajaran baru cukup mempengaruhi inflasi.

Model terbaik diperoleh berdasarkan pemodelan ARIMAX dengan variabel yang telah ditetapkan. Kebaikan model diambil berdasarkan nilai AIC terkecil. Untuk setiap model ARIMAX $(2,0,3)$ didapatkan AIC terkecil yaitu ARIMAX semua peubah $X$ dengan nilai AIC sebesar 109.19. 
Tabel 4: Dugaan parameter model ARIMAX lag dan dummy

\begin{tabular}{lrrrr}
\hline \multicolumn{1}{c}{ Peubah } & \multicolumn{1}{c}{$\begin{array}{l}\text { Dugaan } \\
\text { Parameter }\end{array}$} & \multicolumn{1}{c}{ Galat Baku } & $t$-hitung & $p$-value \\
\hline Intersep & -0.1729 & 0.3775 & -0.4580 & 0.6468 \\
MA(1) & 0.0061 & 0.6599 & 0.0092 & 0.9926 \\
MA(2) & 0.3383 & 0.3597 & 0.9405 & 0.3469 \\
MA(3) & -0.1286 & 0.1828 & -0.7035 & 0.4816 \\
AR(1) & 0.2498 & 0.6068 & 0.4117 & 0.6806 \\
AR(2) & -0.4485 & 0.4089 & -1.0969 & 0.2727 \\
Suku bunga(lag6) & 0.0734 & 0.0585 & 1.2547 & 0.2102 \\
GT TKU (lag 3) & -0.0005 & 0.0011 & -0.4546 & 0.6575 \\
GT Sandang (lag4) & 0.0012 & 0.0025 & 0.4800 & 0.6346 \\
GT Makanan (lag 0) & 0.0021 & 0.0020 & 1.0500 & 0.2832 \\
Dummy(lag0) & 0.3261 & 0.1879 & 1.7355 & $\mathbf{0 . 0 8 2 6}$ \\
\hline
\end{tabular}

\subsection{Diagnostik Model}

Pemodelan regresi linier memiliki asumsi yang harus dipenuhi yaitu sisaan yang tidak saling berkorelasi (white noise) dan sisaan yang berdistribusi normal. Pengujian model terbaik dilakukan berdasarkan hasil model terbaik yang telah didapatkan $\operatorname{ARIMAX}(2,0,3)$ semua peubah. ARIMAX $(2,0,3)$ semua variabel menunjukkan nilai probabilitas ( $p$-value) lebih besar dari taraf signifikan sehingga model dapat diterima. Pengujian sisaan menunjukkan tidak ada autokelasi dimana nilai probabilitas lebih kecil dari taraf signifikan. Untuk ARIMAX $(2,0,3)$ semua variabel semua asumsi sudah terpenuhi.

\subsection{Evaluasi Peramalan dan Perbandingan Model}

Peramalan dilakukan untuk memastikan keakuratan ramalan dari model. Hasil ramalan inflasi akan ditampilkan untuk 6 bulan kedepan dibandingkan terhadap nilai aktualnya. Untuk model ARIMAX $(2,0,3)$ semua peubah $X$ nilai ramalannya terhadap inflasi akan disajikan Gambar 5.

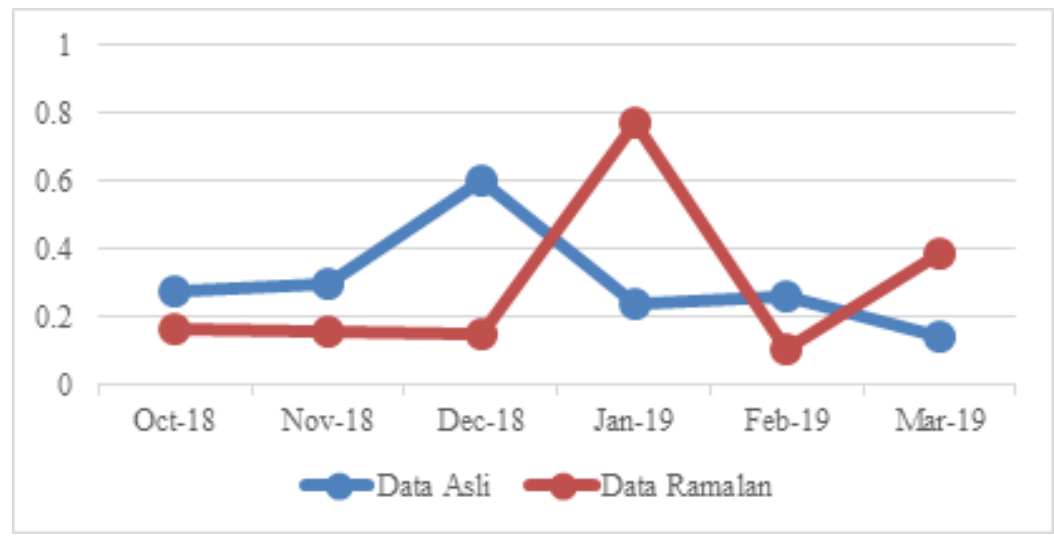

Gambar 5: Plot hasil ramalan semua peubah $X$ 
Pada Gambar 5 menunjukkan bahwa ramalan semua peubah $X$ hasil peramalan antara data asli dan data ramalan terdapat sedikit perbedaan. Namun hasil peramalan model tersebut telah mendekati data asli. Hasil ramalan dapat dilihat melalui hasil plot perbandingan ARIMAX $(2,0,3)$ semua variabel data aktual dengan data ramalan. Hal ini dipengaruhi oleh trends pencarian Google Trends dengan peristiwa atau kejadian inflasi yang berlangsung.

\subsection{Pemilihan Model Terbaik}

Berdasarkan penelitian yang telah dilakukan, pemilihan model terbaik diambil dari hasil pemodelan ARIMA dan ARIMAX. Kedua pendekatan model deret waktu yang digunakan untuk menganalisis ramalan menunjukkan hasil ramalan cukup yang berbeda. Hasil ramalan dengan $\operatorname{ARIMA}(2,0,3)$ memperlihatkan nilai yang hampir sama dengan nilai yang dikeluarkan BPS. Penambahan variabel pada model ARIMAX $(2,0,3)$ semua peubah $X$ terdapat perbedaan yang jelas. Hal ini disebabkan penambahaan dari peubah Google trends pada model.

Model terbaik diambil dari nilai AIC terkecil, penduga parameter signifikan, nilai MSE dan nilai MAPE terkecil. Tabel 5 menunjukkan keseluruhan model penelitian dengan nilai MSE dan MAPE. Berdasarkan nilai MSE dan MAPE terkecil dari keseluruhan model maka model $\operatorname{ARIMAX}(2,0,3)$ semua peubah $X$ yang paling mendekati model terbaik. Hal ini ditunjukkan dengan hasil MSE sebesar 0.1 dengan penambahan beberapa peubah.

Tabel 5: Nilai MSE dan MAPE.

\begin{tabular}{llr}
\hline Model & MSE & \multicolumn{1}{c}{ MAPE } \\
\hline ARIMA $(2,0,3)$ & 0.0289 & 49.6724 \\
ARIMAX $(2,0,3)$ semua peubah & 0.1007 & 103.2589 \\
\hline
\end{tabular}

\section{Simpulan}

Berdasarkan hasil penelitian dapat disimpulkan bahwa hasil eksplorasi data Google trends berdasarkan tujuh kelompok pengeluaran diperoleh transportasi dan pendidikan. Berdasarkan hasil pemodelan dari eksplorasi data diperoleh model terbaik yaitu $\operatorname{ARIMAX}(2,0,3)$ semua peubah $X$. Hasil ramalan $\operatorname{ARIMAX}(2,0,3)$ semua peubah $X$ menunjukkan hasil ramalan yang cukup baik. Karena hasil ramalan hampir sama dengan data asli BPS. Dengan demikian, maka dapat disimpulkan bahwa penelitian dengan menggunakan data Google trends cukup baik untuk dilakukan peramalan khususnya kota DKI Jakarta tetapi tidak dapat digunakan sebagai acuan kebijakan keputusan. 


\section{Daftar Pustaka}

[BPS] Badan Pusat Statistik. (2017). Indeks Harga Konsumen dan Inflasi DKI Jakarta. Jakarta(ID): BPS.

[BPS] Badan Pusat Statistik. (2019). Perkembangan Indeks Harga Konsumen Provinsi DKI Jakarta. Jakarta(ID): BPS.

Choi, H., \& Varian, H. (2012). Predicting the Present with Google Trends. Economic Record, 88: 2-9.

Eksiandayani, S. (2016). Pemodelan Peramalan Inflasi Umum dan Inflasi menurut Kelompok Pengeluaran Indonesia dengan Metode Hibrida ARIMAX [tesis]. Surabaya(ID): Institut Sepuluh Nopember.

Pati, R. K., \& Padhi, S. S. (2017). Quantifying potensial tourist behavior in choice of destinition using Google Trends. J. Tourism Management Perspecives, 24: 34-47.

Pratidina. (2012). Analisis pengaruh guncangan eksternal dan internal terhadap inflasi di Indonesia [tesis]. Bogor(ID): Institut Pertanian Bogor.

Stephani, C., Suharsono, A., \& Suhartono. (2015). Peramalan Inflasi Nasional Berdasarkan Faktor Ekonomi Makro Menggunakan Pendekatan Time Series Klasik dan ANFIS. J. Sains Dan Seni ITS, 4(1): 67-72.

Vicente, M. R., Lopez-Menendez, A. J., \& Perez, R. (2015). Forecasting unemployment with Internet Search Data: Does it help to Improve Predictions when Job Destruction is Skyrocketing? J. Technological Forecasting and Social Change, 93: 132-139.

Wei, W. W. S. (2006). Time Series Analysis: Univariate and Multivariate Method 2nd Edition. New York(US): Pearson Education, Inc. 